\title{
A Case for Real Estate Inclusion in Pension Funds Mixed-Asset Portfolios in Tanzania
}

\author{
Moses Mpogole Kusiluka, Sophia Marcian Kongela \\ Department of Land Management and Valuation, Ardhi University, Dar es Salaam, Tanzania \\ Email:kusiluka@gmail.com
}

How to cite this paper: Kusiluka, M. M., \& Kongela, S. M. (2020). A Case for Real Estate Inclusion in Pension Funds Mixed-Asset Portfolios in Tanzania. Current Urban Studies, 8, 428-445.

https://doi.org/10.4236/cus.2020.83024

Received: June 15, 2020

Accepted: September 13, 2020

Published: September 16, 2020

Copyright $\odot 2020$ by author(s) and Scientific Research Publishing Inc. This work is licensed under the Creative Commons Attribution International License (CC BY 4.0).

http://creativecommons.org/licenses/by/4.0/

(c) (i) Open Access

\begin{abstract}
Traditionally, pension funds invest heavily in fixed income securities. More recently, pension funds have also been increasing their exposure to nonconventional asset classes including real estate. Over the last two decades, pension funds in Tanzania have increased their real estate allocations to more than $18 \%$, which is relatively higher compared to the international practice. This paper looks into investment practice by pension funds in Tanzania with a view to examining whether real estate inclusion contributes to the attainment of optimal portfolios. The study entails mean-variance optimisation analysis of pension funds' portfolios, covering a period between 2009 and 2018. Findings show that real estate inclusion in pension funds' portfolios has risk reduction potential. This paper enriches literature on pension funds' investment practice, particularly those in the countries that are characterised by nascent capital markets institutions. The study also compares conventional literature on pension funds investment practice and the reality on the ground.
\end{abstract}

\section{Keywords}

Real Estate Investment, Portfolio Allocation, Pension Funds' Investments, Tanzania

\section{Introduction}

Capital intensiveness is one of the idiosyncratic features of real estate investment. This is particularly more valid for market settings that are characterised by infant financial market institutions epitomising the majority of sub-Saharan African countries, among other developing countries. Most of these countries are still building prerequisite market economy institutions in order to attract and 
promote private investment, both local and foreign. Most of these countries are also among the poorest in the world with a small base of private investors. These countries experience high population growth, rapid urbanisation, acute shortage of affordable housing and modern urban facilities, proliferation of informal settlements and many other urban management related problems. In the absence of a strong private sector base, large investment projects and schemes are mostly carried out by state or quasi state-owned institutions.

Real estate development in these countries is largely dominated by state-owned or state-sponsored institutions. Pension funds are among the institutions that play a key role in the real estate sector. Pension funds' real estate investments account for a significant portion of ultra-modern high-rise buildings redefining the skylines of some large urban centres in some sub-Saharan African countries. Active participation of pension funds in real estate investment is arguably in line with their investment policies and reflects their asset-liability requirements. It is noteworthy that contributing members of most of the pension funds in these countries are of relatively young age, giving a long investment horizon of their pension contributions. Pension funds find real estate to be an attractive investment vehicle due to, among other factors, income and capital stability, capital growth and low volatility of returns.

Just like most African countries, Tanzania is still at its infancy in developing its real estate markets. The market is dominated by few institutional investors, largely pension funds and a state-owned enterprise, namely National Housing Corporation (NHC). Foreign institutional real estate investors are almost non-existent. As many studies suggest, African countries are still regarded by many institutional real estate investors in developed countries as high risk investment destinations (Rothenberger, 2010; Lim et al., 2006). This stereotype has persisted irrespective of institutional reforms implemented in many African countries over the last two decades. Although the reforms have significantly improved investment environment for both public and private investors, their impact is still largely confined to local investors (Kusiluka, 2012). Real estate sector is among the sectors that have significantly benefited from the reforms as many local institutional investors, particularly pension funds, have increased their portfolio allocations to real estate markedly.

The steadfast increase in pension funds' exposure to real estate investment against the backdrop of the sector market opacity has attracted the attention of researchers, regulators and policy makers on the suitability of the investment vehicle for pension funds. This study is an attempt to examine whether real estate inclusion contributes to the attainment of optimal portfolios. It entails a mean-variance optimisation analysis of Tanzania state-sponsored pension funds' portfolios, covering a period between 2009 and 2018. The paper consists of ive main sections, namely: introduction, literature review, methodology, results and discussion and conclusion. 


\section{Literature Review}

\subsection{Pension Funds Investment Practice}

Globally, pension schemes have been in existence for many centuries and they originally targeted people injured in wars or industry, widows and aged people but with time they evolved and started covering poor people by protecting them against suffering caused by loss of income. Today, pension schemes exist as large institutions playing a major role in the social security systems. The schemes are in two main categories, namely defined contribution plans and defined benefits plans. Whereas in defined contribution plans pension benefits are not specified other than that at retirement, in defined benefits plans benefits are specified and would normally depend on years of service and the level of wages or salary of a member (Sharpe et al., 1999). In the defined benefits plan system, the pension plan sponsor accepts liability for future pension payments.

The primary objective of pension funds is to accumulate sufficient assets, through contributions and investment income to satisfy pension obligations on a timely basis (Sharpe et al., 1999). Administrators of pension funds have a fiduciary responsibility to the insured persons, which forces them to be prudent in carrying out their investment duties (Tamagno, 2000). Pension funds pool resources from beneficiaries and employers and invest them in various investment media. Most of the pension funds' aggregate assets are invested for a long term (Ryck, 1998). However, the liability structure is one of the main factors considered when deciding on the investment strategy of a pension plan (Mensonides, 1998). Whereas pension funds with young members are more likely to invest in long-term investments because they have few short-term obligations, mature pension funds need to carefully monitor their solvency conditions and liquidity of their investments to be able to honour their obligations.

Traditionally, pension funds around the world have been investing largely in fixed income assets, traditional equities and cash. However, this conventional asset allocation practice focusing on low-yield fixed income assets presents potential difficulties in meeting future obligations (APREA, 2010). As a result, over the recent years, pension funds have been extending their investment horizon by increasing their exposure to alternative assets, mainly real estate, private equity, hedge funds, infrastructure and commodity (Andonov et al., 2014; Aubry et al., 2017). Aging population is one of the factors that are increasingly putting pension funds, especially those in developed countries, under pressure to achieve portfolio diversification in order to meet their significantly increasing liabilities in an effective risk-adjusted manner (Newell, 2010).

\subsection{Pension Funds Exposure to Real Estate}

Viewed from a neo-institutional theory perspective, pension fund institutions are highly susceptible to transactions costs. Transaction costs arise due to the cost of time and effort invested in researching, creating, implementing, administering, 
monitoring and enforcing policies (Shahab \& Viallon, 2019). They include the costs of time spent on each transactional activity and the direct monetary expenses incurred in the policy design, implementation or participation processes (Shahab et al., 2018). Pursuit of real estate investment exacerbates the situation because the process entails many transaction costs generating activities. This is mainly due to the lengthy investment acquisition and management processes involved. Despite the inherent transaction costs, pension funds still find real estate to be a worthwhile investment mainly due to its income and capital stability, steady capital growth and low volatility of returns (Newell, 2010; Kusiluka, 2012).

Although real estate is less favourable compared to the traditional pension funds' investment vehicles, its increasing importance as an asset class among institutional investors has attracted pension funds, among other institutional investors, to include it in their portfolios. For instance, in the USA, since the 1950s allocation to real estate has been kept in the range of $0 \%$ to $17 \%$ (Worzala \& Bajtelsmit, 1993). The situation has been more or less similar in the UK over the same period of time, albeit prior to 1980s some isolated cases of UK pension funds had allocated up to over $20 \%$ to real estate (IPF, 1993). Some recent studies show that real estate is the most important alternative asset commanding portfolio allocation of above 5\% (Andonov et al., 2013; Andonov et al., 2014; Van Nieuwerburgh et al., 2015). More recently, average real estate investment holdings by pension funds in the USA, UK, Germany, Netherlands, Switzerland, Portugal, Finland, Canada and Australia have ranged between 3.4\% and 12\% (OECD, 2013; PREA, 2006).

However, liquidity concerns associated with real estate investment have forced pension funds regulators in some countries to set real estate allocation limits. For instance, in Serbia and Brazil pension funds are permitted to allocate only up to $4 \%$ and $8 \%$ respectively. Some sub-Saharan countries such as Uganda, Zambia, Kenya and Tanzania have set a ceiling of 30\% real estate allocation (OECD, 2017). However, in the wake of advancement in financial engineering, real estate is increasingly becoming a liquid investment, which should allay illiquidity fears. This is however more practical in developed countries, most of which have well established and functioning financial markets. Pension funds, among other institutional investors, in those countries are increasingly investing in indirect real estate assets, both listed and unlisted (Andonov et al., 2013; Van Nieuwerburgh et al., 2015). In some countries such as Australia, Belgium, Canada and Denmark pension funds are free to allocate up to $100 \%$ to real estate assets (OECD, 2018).

Some studies, based on asset return mean-variance optimization, suggest a range of between $15 \%$ and $25 \%$ to be the optimal allocation to real estate assets in mixed-asset portfolios (Hoesli \& Hamelink, 2004). However, most of the pension fund managers, apart from looking at asset returns and variances, also consider changes in pension funds liabilities and their covariance with asset returns (Craft, 2005). Many other investors pursue their own asset allocation poli- 
cies which sometimes differ significantly from the proposed allocations. Many investors are increasingly not giving real estate special treatment; they rather look at it just as an investment vehicle similar to other assets (Hoesli et al., 2002).

Very limited literature exists on real estate allocation in African pension funds' and other institutional investors' mixed-assets portfolios. Kwaku (2007) observes that portfolios of institutional investors in Africa are composed of real estate (15.5\%), government securities (25\%), stock market securities (47\%), private equity $(0.4 \%)$ and others (12.1\%). Newell et al. (2002) point out that insurance companies and pension funds in South Africa allocate an average of $8 \%$ of their portfolio to real estate. Over the last two decades, pension funds in Tanzania have on average been allocating between $20 \%$ and $40 \%$ to real estate (Kusiluka, 2012; Kongela, 2013).

\subsection{Real Estate Sector in Tanzania}

When Tanzania achieved its independence in 1961, the level of urbanization was only $4.8 \%$ compared to $31 \%$ in 2018 (Kusiluka et al., 2017). Soon after independence, some initiatives were taken to deal with urbanization related challenges. The focus was mainly on addressing land rights and housing problems in urban areas because interventions made during colonial period were inadequate, short-lived and covered a very small section of the population. One of the important steps taken by the government was to review land and real estate ownership related policies and legislation in order to promote equitable access to land.

In 1967, the government adopted socialist policies, popularly known as ujamaa. In the course of implementing ujamaa which was promulgated through Arusha Declaration of 1967, some pieces of legislation aimed at strengthening government role in direct participation in the real estate market were enacted. For instance, in 1971, the Acquisition of Buildings Act was enacted. The legislation, among others, provided for the nationalisation of private rental properties whose market values were over TZS 100,000 (equivalent of $£ 6,000$ then) or whose rental values were over TZS 833.3 per month (Meredith, 2006). Public servants were also prohibited from owning rental buildings.

In 1962, the National Housing Act No. 45 was enacted. The Act provided for the establishment of National Housing Corporation (NHC) whose main functions were to lend, guarantee or provide finance to local authorities and individuals for the construction and improvement of buildings and approved housing schemes (Kironde et al., 2003). Another notable government initiative was the establishment of Tanzania Housing Bank (THB) in 1973. The main objectives of THB were to mobilize savings and resources for housing development, promote housing development, and provide technical and financial assistance for owner-occupied housing. It is estimated that about 36,000 housing units were built using THB loans (Kusiluka, 2012). Due to persistent operational problems, THB collapsed in 1995. While THB collapsed, NHC to date remains to be the largest real estate owner and a real estate 'market mover' in Tanzania. 
In the mid 1980s, Tanzania reverted to market economy policies. The shift involved major institutional change which witnessed significant changes in legislation and investment facilitation institutions. Some of the key pieces of legislation enacted in the course of the reforms and which have had major impact on the real estate sector include the Land Act Cap. 113, the Village Land Act Cap. 114, Public Corporations Act Cap. 257, Banking and Financial Institutions Cap. 342, Tanzania Investment Act Cap 38, Capital Markets and Securities Act Cap. 79 and Mortgage Finance (Special Provisions) Act of 2008. The changes in legislation also involved repealing or amending some laws that were considered to be an impediment to the smooth functioning of market economy institutions and systems. Some of the laws that were repealed include the Land Ordinance of 1923 and the Rent Restriction Act of 1984.

Reforms have promoted growth in the real estate, among other sectors. Both public and private sector investors have been attracted into the sector. Pension funds too started investing significantly in real estate in the wake of the institutional reforms. The last two decades have also witnessed the entry of foreign investors in the real estate sector. However, the foreign real estate investors sector is still small and has confined itself to up-market commercial, retail and residential properties, mainly in Dar es Salaam which is by far the country's largest city, with an estimated population of more than 5 million.

Prior to the reforms, pension funds in Tanzania were largely investing in fixed-income securities, largely treasury financial instruments and cash. In the wake of liberalization, pension funds began spreading their investments across a broader spectrum of investments. In fact, the enactment of the Public Corporations Act No. 2 of 1992 paved way for pension funds, among other parastatal organizations, which formerly used to invest heavily in treasury securities, to introduce non-traditional investments in their portfolios (Kusiluka, 2012). The legislation, among other things, liberalized investment policies of state-owned enterprises (SOEs).

Over the last two decades pension funds in Tanzania have made noticeable exposure to real estate. With their direct real estate investment value estimated at about TZS 1.8 trillion in 2018, pension funds have become the second largest real estate investors in Tanzania, after NHC whose real estate investment portfolio was valued at TZS 4.1 trillion in the same year. NHC has maintained its leading role in the provision of housing and non-residential real estate in urban areas. Figure 1 shows the growth trend of real estate investment held by pension funds and NHC over the recent years.

As shown in Figure 1, over a period of 10 years, both pension funds and NHC recorded significant growth in real estate investment value. Whereas NHC real estate portfolio value average annual growth over the period was $17.2 \%$ that of pension funds was $23.9 \%$. The growth trend is mainly attributed to a significant addition of a stock of buildings, real estate revaluation and upward rental reviews coupled with a booming market during the period. In 2017, NHC total 


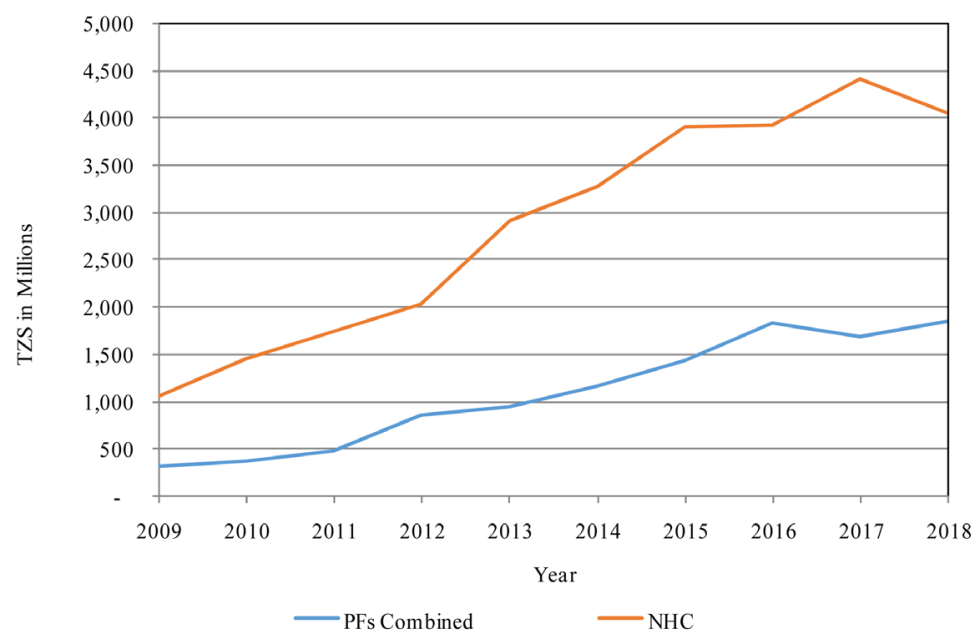

Figure 1. NHC and combined pension funds real estate investment value between 2009 and 2018.

portfolio was valued at TZS 4.4 trillion, which is the highest value ever recorded. Pension funds recorded their peak value of TZS 1.8 trillion in 2018.

\subsection{Pension Funds Investment Practice in Tanzania}

All major government sponsored pension funds in Tanzania are contributory pay-as-you-go defined benefit schemes (John et al., 2017). Until February, 2018 there were five government sponsored pension funds in Tanzania, namely National Social Security Fund (NSSF), Parastatal Pensions Fund (PPF), Public Service Pension Fund (PSPF), Local Authorities Pensions Fund (LAPF) and Government Employees Pension Fund (GEPF). Each of these pension funds was established by an Act of Parliament. In February 2018, the Public Service Social Security Fund Act was enacted. The Act literally provides for, among other things, merging of four pension funds namely PSPF, PPF, LAPF and GEPF into one scheme, namely the Public Service Social Security Fund (PSSSF). The newly established PSSSF caters for public service employees. On the other hand, the Act establishing NSSF was also amended so that the fund is confined to drawing its members only from employees in the private sector, self-employed, foreigners and employees in international organizations. Therefore, currently there are only two main pension funds in Tanzania. However, this paper covers the period prior to the establishment of PSSSF and amendment of the NSSF Act.

Members' contributions and income from investments are the principal sources of funds for the pension funds. All employers in the formal sectors are required by law to remit to the respective pension funds $20 \%$ of their employees' gross salary every month. The $20 \%$ contribution is shared between the employee and the employer by either each one contributing $10 \%$ or by the employer contributing $15 \%$ and the employee contributing 5\%. Employees' contributions are withheld from salaries and remitted to the respective pension funds by their employers. Accordingly, each month pension funds receive a significant amount of cash. 
Member's contributions are vested in the respective pension funds until such time when they become payable to the member. Members are therefore restricted from assigning, transferring or attaching any of such sums to a debt or claim against them. However, members are allowed to use part of their entitlements as collateral for a home mortgage not exceeding $50 \%$ of the total benefits entitlement. With such a guaranteed monthly cash inflow coupled with expansion of the formal sector over time, pension fund assets have grown considerably over the last 20 years. Over the last two decades, pension funds in Tanzania have had about TZS 1 trillion available for investment annually and their assets have accounted for about $10 \%$ of the GDP and $20 \%$ of total financial sector assets $(\mathrm{Ku}-$ siluka, 2012).

Out of the five large pension funds in Tanzania that were in existence until 2018, NSSF and PPF were relatively older and had been in the real estate market for a much longer period. The two pension funds experienced both eras that define Tanzania's real estate market i.e. socialist and post socialist eras. PSPF and LAPF came into existence as typical pension fund institutions (body corporate) in 1999 and 2000 respectively and they started owning real estate investment in 2004. GEPF was the latest comer into real estate sector compared to the rest of the pension funds, mainly owing to its small size. Prior to 2013, GEPF operated as a provident fund only catering for government employees working under contractual terms and thus not covered by other pension funds.

As shown in Figure 2, during the 10 years covered by the study, pension funds' investments grew markedly. In 2009, the value of a combined investment portfolio was TZS 2.3 trillion but in 2018 the value had reached TZS 8.7 trillion, which is an average of $15.9 \%$ annual growth rate and a $278 \%$ portfolio growth in a single decade.

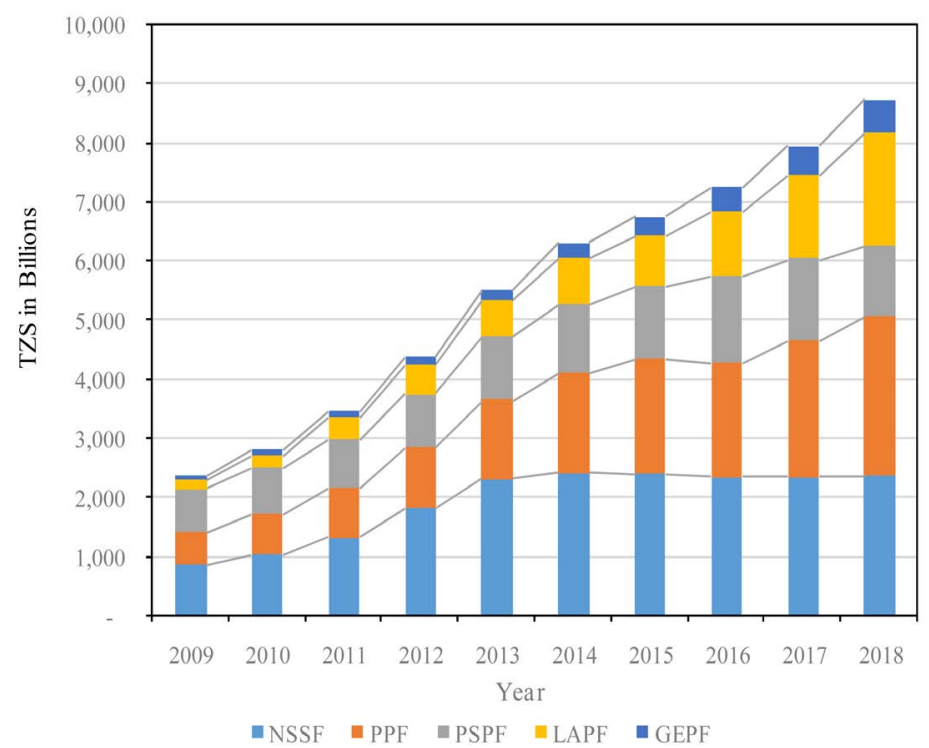

Figure 2. Growth trend of pension funds' investment portfolios in Tanzania between 2009 and 2018 


\section{Methodology}

A combined portfolio of state-sponsored pension funds in Tanzania is analysed by applying mean-variance optimisation. The analysis is based on data from the respective pension funds' financial statements and financial reports covering the period between 2009 and 2018. Mean-variance optimisation analysis focuses on determining whether the pension funds maintain efficient portfolios. To avoid computing covariance between every pair of all securities forming the portfolios of the pension funds, which would have resulted into a large number of covariance values, assets were grouped into three main categories namely, real estate, fixed income assets and equities. The decision was primarily based on the fact that an efficient frontier is based on an idealised model of the way investments work. When a large number of computations are applied to the model they tend to amplify the error between the model and reality hence asset grouping was opted for. The following portfolio return $\left(E\left(r_{p}\right)\right)$ and portfolio risk $\sigma_{p}$ formulae were applied:

$$
\sigma_{p}=\sqrt{\left(\left(w_{R e}^{2} \sigma_{R e}+w_{F i}^{2} \sigma_{F i}+w_{E q}^{2} \sigma_{E q}\right)+\left(2 w_{R e} w_{F i} \operatorname{Cov}(R e, F i)+2 w_{R e} w_{E q} \operatorname{Cov}(R e, E q)+2 w_{F i} w_{E q} \operatorname{Cov}(F i, E q)\right)\right)}
$$

where, $E\left(r_{p}\right)$ is portfolio returns for the period, $w_{R e}$ is portfolio weighting for real estate, $W_{F i}$ is portfolio weighting for fixed income assets, $W_{E q}$ is portfolio weighting for equities, $E\left(r_{R e}\right)$ is real estate returns, $E\left(r_{F i}\right)$ is fixed income assets returns, $E\left(r_{E q}\right)$ is equities returns, $\sigma_{p}$ is portfolio standard deviation (risk) for the period, $\sigma_{R e}$ is standard deviation of real estate returns, $\sigma_{F i}$ is standard deviation of fixed income assets returns, $\sigma_{E q}$ is standard deviation of equities returns, $\operatorname{Cov}(R e, F i)$ is covariance between real estate and fixed income assets returns, $\operatorname{Cov}(R e, E q)$ is covariance between real estate and equities returns, $\operatorname{Cov}(F i, E q)$ is covariance between fixed income assets and equities returns.

Data collection also involved interviews with 14 respondents of whom ten were investment officials of the five pension funds, two NHC managers and one Capital Markets and Securities Authorities (CMSA) official. Interviews were useful in explaining pension funds' investment decisions and trends. Other official reports, publications and websites formed a source of some secondary data.

\section{Results and Discussion}

\subsection{Entry of Pension Funds in the Real Estate Market}

It was noted from the interviews with investment managers of the five pension funds that one of the main challenges that pension funds in Tanzania have been facing is getting the right investment opportunities, given the limited investment options available to leverage diversification benefits, capital growth, and stable income and attractive returns. It is worth noting that, as depositories of their members' monies, pension funds are bound to ensure that monies are invested 
in safe and viable ventures. This was noted to be partly aggravated by the fact that the law in Tanzania did not permit pension funds to own cross-border investments thereby limiting their space for making investment choices and subjecting them to stiff competition for the few good investment vehicles available locally. The situation was even much harder in the period prior to the enactment of the Public Corporations Act of 1992, when pension funds were obliged to allocate most of their assets to treasury securities. For instance, the National Provident Fund (now NSSF) was required by law, to invest at least 75\% of its investible funds in government securities.

By enacting Public Corporations Act, the government withdrew its direct supervision of the public corporations' investment activities, which left investment decision-making to the respective corporations. As a result of this decision, noticeable ownership of investment real estate amongst pension funds in Tanzania gained momentum after 1992. The properties owned by pension funds prior to the early 1990s were mainly operational buildings (Kongela, 2013). Today, pension funds invest across all sectors of real estate.

The value of real estate investment held by pension funds has grown markedly over the last 10 years. The combined value of real estate investment in 2009 was TZS 308.2 billion and in 2018 it had reached TZS 1.8 trillion, which is 501\% growth in just 10 years. Some of the main reasons given for the rapid growth include significant increase in revenues from members' contributions due to a steady increase in the number of members, increase in salaries and assets revaluation gain. NSSF and PPF started investing in real estate much earlier compared to other pension funds, understandably due to their large size. On the other hand, GEPF apparently due to its small size was the latest to embark on real estate business and until 2018 it was still the smallest real estate investor among the pension funds. PSPF came in relatively late but it carried out large scale projects culminating into two of the largest and modern buildings, namely Golden Jubilee and PSPF Tower, both situated within the central business district of Dar es Salaam city.

The entry of pension funds in the real estate investment sector in Tanzania has significantly changed the sector. They started investing in prime commercial properties but over time some of them, particularly NSSF and PPF, extended their investment to residential properties. NSSF and PPF have also been engaged in the construction and financing the construction of a wide range of affordable housing including halls of residence for higher learning institutions and staff housing for various government institutions. Figure 3 shows the trend of real estate allocations by the five pension funds over some recent years.

As shown in Figure 3, over the last decade, pension funds' direct real estate allocation has generally been increasing, averaging above $20 \%$. The average allocation was well in line with the statutory ceiling of $30 \%$. Over the entire period, NSSF had the highest allocation averaging at $28.8 \%$ while at the lower extreme 


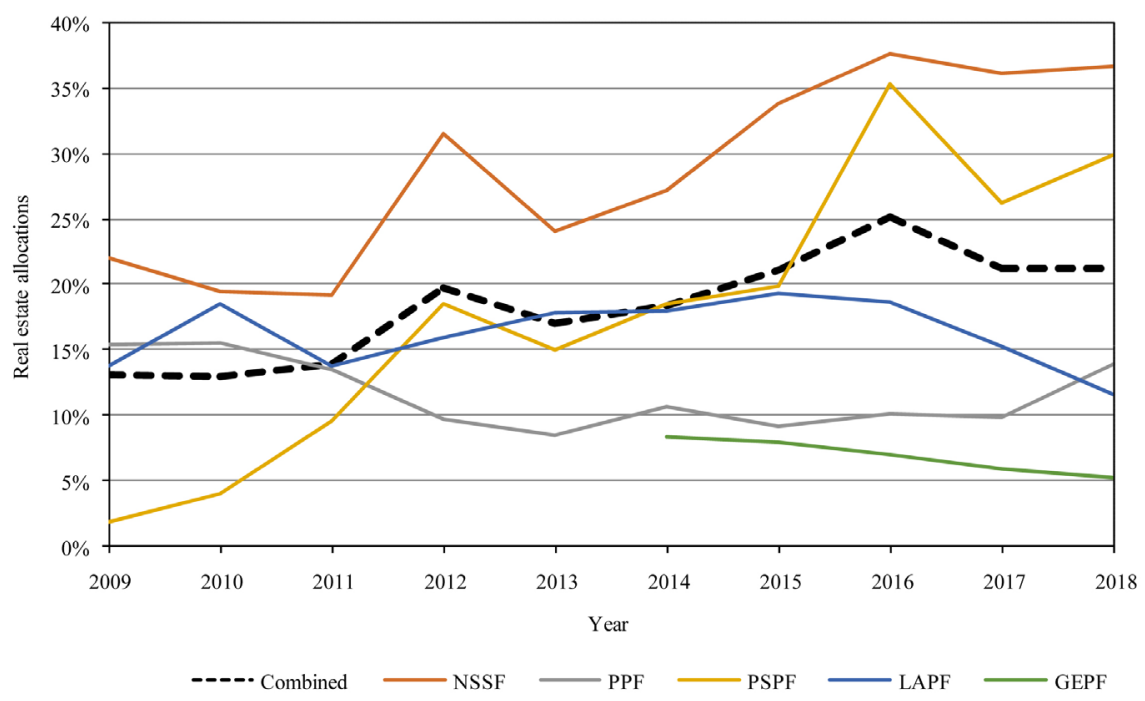

Figure 3. The trend of pension funds' real estate allocations in Tanzania between 2009 and 2018.

was GEPF whose real estate allocation was generally declining over time, recording the lowest allocation of 5.2\% in 2017. It is also evident from Figure 3 that real estate allocations by pension funds in Tanzania are much higher than of those in their counterparts in developing countries. The relative higher real estate allocations are apparently reflective of the young age structure of the population of Tanzania, which imply a long-term liability structure of pension funds. Another common explanation for the high real estate allocation was noted to be existence of limited investment options suitable for pension funds, considering the intensity of regulation exercised on pension funds operations.

\subsection{The Effect of Real Estate in a Mixed-Asset Portfolio}

Until 2015, pension funds had much more flexible asset allocation policies. For instance, for some years NSSF investment policy provided for $10 \%$ allocation to real estate assets. PPF investment policy, on the other hand, provided for a much higher and flexible range of 32\% - 48\% for real estate allocation (Kongela, 2005). Even NSSF investment policy was not watertight; it gave managers some freedom to take on any new investment vehicle provided there was a strong business justification (Kusiluka, 2012). Observations, however, show that some pension funds had at times had real estate allocations higher than the proportions spelt out in their respective investment policies. However, the situation changed when the Social Security Schemes Investment Guidelines of 2015 took effect.

From time to time, the Social Security Regulatory Authority (SSRA) has issued guidelines on investment matters including asset allocation for pension funds. Being financial institutions coupled with their major role in the national financial system, pension funds were also noted to be regulated by the central bank. For instance, the Social Security Schemes Investment Guidelines of 2015 made under Section 26(2) of the Social Security (Regulatory Authority) Act No. 
8 of 2008 set a ceiling of real estate portfolio allocation at $30 \%$. Any pension fund planning to allocate more than $30 \%$ to real estate assets must obtain permission from the central bank. The guidelines also require that returns on investments other than treasury investments be above returns on treasury bills and treasury bonds. The 30\% real estate allocation ceiling was also noted to be mindful of the liquidity risk associated with direct real estate investment which forms the majority of pension funds' real estate investment portfolio. Table 1 shows asset weightings and returns for the five pension funds combined.

It is clear from Table 1 that the pension funds have been heavily investing in fixed income assets. Fixed income assets, accounting for $67.9 \%$ portfolio allocation, largely include government securities, certificates of deposits, commercial papers, corporate bonds and term loans. Historically, pension funds in Tanzania have been very important participants in the treasury securities market. However, over the period covered in this analysis, the trend of investment in this asset group was slightly declining in favour of real estate and equities. Average allocation to real estate for the period was $18.4 \%$ and to equities was $13.7 \%$. It is clear from the analysis that real estate allocation is well below the $30 \%$ ceiling stipulated in the Social Security Schemes Investment Guidelines of 2015 and it is within the range recommended in some literature (e.g. Hoesli \& Hamelink, 2004).

During the period, annual allocations to real estate and equities were generally increasing by $6.7 \%$ and $3.9 \%$ respectively. Some of the main reasons for the trend include liberalisation of public corporations' investment policies in 1992

Table 1. Asset weighting (\%) and returns (\%) of a combined pension fund portfolio from 2009 to 2018.

\begin{tabular}{ccccccc}
\hline Year & $\begin{array}{c}\text { Real estate } \\
\text { weighting } \\
\text { wRe }\end{array}$ & $\begin{array}{c}\text { Real estate } \\
\text { returns E } \\
(\mathrm{RRe})\end{array}$ & $\begin{array}{c}\text { Fixed income } \\
\text { assets } \\
\text { weighting wFi }\end{array}$ & $\begin{array}{c}\text { Fixed income } \\
\text { assets returns } \\
\text { E(RFi) }\end{array}$ & $\begin{array}{c}\text { Equities } \\
\text { weighting } \\
\text { WEq }\end{array}$ & $\begin{array}{c}\text { Equities } \\
\text { returns } \\
\text { E(REq) }\end{array}$ \\
\hline 2009 & 13.1 & 5.6 & 75.3 & 8.9 & 11.5 & 4.1 \\
2010 & 13.0 & 4.9 & 76.7 & 9.4 & 10.3 & 4.7 \\
2011 & 13.9 & 4.3 & 74.9 & 11.1 & 11.2 & 12.9 \\
2012 & 19.7 & 2.7 & 69.5 & 9.9 & 10.8 & 6.1 \\
2013 & 17.1 & 2.8 & 66.7 & 15.6 & 16.2 & 4.0 \\
2014 & 18.3 & 2.7 & 62.3 & 12.5 & 19.3 & 6.1 \\
2015 & 21.2 & 2.5 & 64.5 & 12.8 & 14.4 & 7.5 \\
2016 & 25.2 & 2.3 & 59.9 & 11.3 & 14.9 & 14.3 \\
2017 & 21.2 & 2.5 & 64.2 & 11.1 & 14.6 & 6.2 \\
\hline Average & 18.4 & 3.3 & 64.8 & 12.0 & 14.0 & 4.6 \\
\hline
\end{tabular}

Source: Annual reports and audited financial statements (2009-2018). 
and growth of capital markets institutions including the establishment of Capital Markets and Securities Authority (CMSA) in 2004 and Dar es Salaam Stock Exchange (DSE) in 1998. Over the same period, government securities were among few attractive investments in terms of both returns and risk measures. Besides, over the same period, average inflation rate stood at about $8 \%$, which is relatively low and thus made treasury securities much more attractive. Pension funds have been a key player at DSE. Figure 4 shows the trend of returns on the three investment categories over a span of ten years.

As depicted in Figure 4, during the period, fixed income assets returns have relatively been high except for 2011 and 2016 when equities outperformed fixed income assets. Equities ranked second but it had the highest volatility of returns. On the other hand, real estate investment had the lowest but the most stable returns. Therefore, measured by the riskiness, equities with a standard deviation of returns of $3.6 \%$ is at the bottom, followed by fixed income assets which has a standard deviation of returns of $2.0 \%$. Real estate, with a standard deviation of returns of $1.2 \%$, had the most stable returns. This is consistent with Newell (2010) and Kusiluka (2012) who underscore stability of real estate income. However, further analysis of returns behaviour reveals portfolio diversification potential. Table 2 presents the correlation matrix of asset returns for the three asset classes.

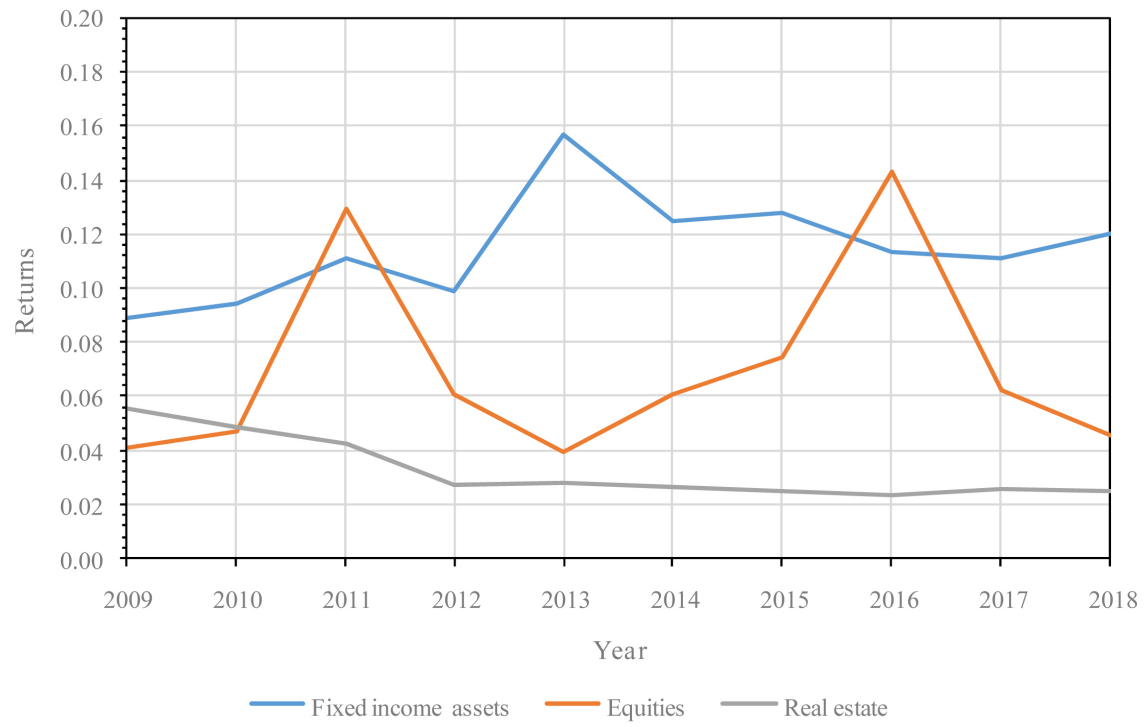

Figure 4. The trend of combined pension return on investments between 2009 and 2018.

Table 2. Correlation matrix of asset returns.

\begin{tabular}{cccc}
\hline & Real estate & Fixed income assets & Equities \\
\hline Real estate & 1.00 & -0.60 & -0.18 \\
Fixed income assets & -0.60 & 1.00 & 0.06 \\
Equities and others & -0.18 & -0.06 & 1.00 \\
\hline
\end{tabular}


Several implications can be drawn from correlation analysis results presented in Table 2. For instance, it is evident that if included in mixed-asset portfolios, real estate has the potential of reducing risk. However, it is also possible that real estate could substantially reduce portfolio return. To avoid this, it would be advisable to have a portfolio with assets whose returns have low correlation coefficients. From Table 2 it is clear that real estate can form efficient portfolios with both fixed income assets and equities. This is because the correlation coefficients between real estate returns and fixed income assets and equities returns are negative i.e. -0.60 and -0.18 respectively. Similarly, the fact that the returns of fixed income assets and equities are not perfectly correlated suggests existence of risk reduction potential when the two assets are combined. Table 3 summarises the various feasible portfolios for pension funds, based on historical returns and asset weighting.

As presented in Table 3, the results of the analysis of the current portfolio consisting of $67.9 \%$ fixed income assets, $18.4 \%$ real estate and $13.7 \%$ equities and others show that the portfolio return is $9.37 \%$ and portfolio risk is $1.29 \%$. Real estate has the potential of reducing portfolio risk but it also reduces returns. For instance, by allocating $60 \%$ of the portfolio to real estate, portfolio risk is reduced from $1.3 \%$ to $0.6 \%$ but portfolio returns is also reduced from $9.4 \%$ to $6.2 \%$. However, the proportions of assets in this portfolio do not represent an efficient diversification of the portfolio. Two better options exist. It is possible to reduce portfolio risk without affecting returns and it is also possible to increase portfolio returns without necessarily increasing portfolio risk.

When the portfolio allocation is adjusted to comprise $70.0 \%$ fixed income assets, $21.0 \%$ real estate and $9.0 \%$ equities its return is not affected. With these asset proportions, portfolio risk is reduced from $1.29 \%$ to $1.27 \%$, which is a $1.55 \%$ reduction in the portfolio risk. On the other hand, when the portfolio is adjusted to comprise $35.5 \%$ fixed income assets, $36.6 \%$ real estate and $27.9 \%$ equities its

Table 3. Portfolio assets compositions, returns and risk.

\begin{tabular}{|c|c|c|c|c|}
\hline \multicolumn{2}{|c|}{ Current Portfolio (Not efficient) } & \multirow{2}{*}{$\begin{array}{c}\begin{array}{c}\text { Real } \\
\text { estate }\end{array} \\
18.4 \%\end{array}$} & \multirow{2}{*}{$\begin{array}{c}\text { Fixed } \\
\text { income assets } \\
67.9 \%\end{array}$} & \multirow{2}{*}{$\begin{array}{r}\text { Equities } \\
13.7 \%\end{array}$} \\
\hline Portfolio composition & & & & \\
\hline Portfolio returns & $9.37 \%$ & & & \\
\hline Portfolio risk & $1.29 \%$ & & & \\
\hline \multicolumn{5}{|c|}{ Efficient Portfolio 1 (return maximized, risk kept constant) } \\
\hline Portfolio composition & & $20.0 \%$ & $71.0 \%$ & $9.0 \%$ \\
\hline Portfolio returns & $9.43 \%$ & & & \\
\hline Portfolio risk & $1.29 \%$ & & & \\
\hline \multicolumn{5}{|c|}{ Efficient Portfolio 2 (risk minimized, return kept constant) } \\
\hline Portfolio composition & & $21.0 \%$ & $70.0 \%$ & $9.0 \%$ \\
\hline Portfolio returns & $9.37 \%$ & & & \\
\hline Portfolio risk & $1.27 \%$ & & & \\
\hline
\end{tabular}


return increases from $9.37 \%$ to $9.43 \%$ but risk remains at $1.29 \%$. If this combination of assets is adopted, portfolio returns would increase by $5.1 \%$.

The analysis above clearly makes a case for inclusion of real estate in mixed-asset portfolios of pension funds and other institutional investors' portfolios. Real estate has the potential of reducing portfolio risk. Besides, real estate investment guarantees income regularity and capital growth. The case for inclusion of real estate in mixed-asset portfolio in Tanzania is further enhanced by the dearth of credible investment options locally mainly due to the infancy of the economy and nascence of capital market institutions.

\subsection{Other Emerging Investment Fronts for Pension Funds}

Beside their interest in real estate, it was noted that pension funds over the last decade also ventured into new areas of investment including infrastructure and manufacturing. Some of the notable projects recently financed by pension funds include the construction of a $0.68 \mathrm{~km}$ toll bridge in Dar es Salaam by NSSF. In this project which is worth TZS 280 billion, NSSF contributed $60 \%$ in anticipation of recovering the money through toll. The bridge was completed in 2016 and by March 2018 about TZS 19.7 billion had been collected in toll (The Citizen Reporter, 2018). In another project, LAPF financed the construction of Msamvu Bus Terminal in Morogoro Municipality. More recently, pension funds have embarked on agro-processing industries. This move is in line with the national Five-Year Development Plan (2017-2023) which is explicit on the government's resolve to promote industrial development. Mkulazi Holding Company Ltd, a company mainly engaged in sugarcane farming and processing, is jointly owned by NSSF and PPF (now PSSSF).

Pension funds were involved in financing the construction of institutional buildings. For instance, pension funds also financed the construction of multi-billion shilling buildings and infrastructure for the University of Dodoma and Hombolo Local Government Training Institute (Kusiluka, 2012). Through a special purpose vehicle, namely Pension Properties Ltd, pension funds financed the construction of the parliament building in Dodoma. In some rare occasions, some pension funds also issued term loans to private individuals.

The practice being experienced in Tanzania is not an exception. A trend is emerging for pension funds around the world to take on non-traditional investments. In recent years, investing in infrastructure as an alternative to the mainstream investment vehicles has become increasingly popular with pension funds as they strive to manage risk (Andonov et al., 2018; Inderst, 2010; Newell, 2010).

\subsection{Limitations}

It should be noted that the real estate allocations considered in this analysis are only those of direct real estate investment. More recently, pension funds in Tanzania have also been investing in private equity real estate companies such as Ubungo Plaza Ltd, International House Properties Ltd, NHC/PPF-IPS Ltd, and 
Pension Properties Ltd. Pension funds are also the majority shareholders of Watumishi Housing Company Ltd., a private Real Estate Investment Trust (REIT). However, for financial reporting purposes, such indirect investments fall under equities. As a result of this, real estate allocations and income for the purpose of portfolio mean-variance analysis were understated by the amount of funds invested in such indirect real estate investment vehicles and the corresponding income that accrued from the respective investments. It is thus clear that the actual real estate allocation by pension funds in Tanzania is slightly higher than what is normally reported under the asset class.

\section{Conclusion}

This paper demonstrates that it is worthwhile including real estate in mixed-asset portfolio due to its potential to reduce risk. Despite the risk reduction potential inherent in real estate assets, pension funds in Tanzania have adopted a random diversification strategy of their portfolio. Their combined portfolio does not reflect efficient diversification as there is still potential for achieving better returns or lowering risk further. Their portfolio consisting of $18.4 \%$ real estate, $67.9 \%$ fixed income assets, and $13.7 \%$ equities had a return and risk of $9.37 \%$ and $1.29 \%$ respectively. Pension funds could have minimised risk, without affecting returns, by adjusting their portfolios to comprise $21.0 \%$ real estate, $70.0 \%$ fixed income assets and $9.0 \%$ equities. This combination would have reduced risk by $1.6 \%$. Alternatively, pension funds could have maximised returns, without increasing risk, by allocating $20.0 \%$ to real estate, $71.0 \%$ to fixed income assets and $9.0 \%$ to equities. The proposed portfolio adjustments would have increased returns by $5.1 \%$.

Both options imply that pension funds should increase their direct real estate investment. This is feasible because their current real estate allocation is still below the statutory ceiling of $30 \%$. Inclusion of real estate in the pension funds' portfolios is further augmented by the scarcity of credible investment vehicles that are capable of preserving capital and guaranteeing a stable stream of income and real estate potential in reducing portfolio risk. However, in order to reduce transaction costs inherent in real estate and to make it a much better and safer investment for institutional investors, policy interventions are required to ensure that transparency in the real estate sector is enhanced. This can be achieved through promotion of capital market-based real estate investments, establishment of real estate information databank institutions and strengthening professional practice standards and ethics in the fields of real estate. The findings of this study are not only relevant to institutional investors in Tanzania but are also useful to similar institutions and policy makers in other developing countries facing similar constraints.

\section{Conflicts of Interest}

The authors declare no conflicts of interest regarding the publication of this paper. 


\section{References}

Andonov, A., Eichholtz, P., \& Kok, N. (2014). Intermediated Investment Management in Private Markets: Evidence from Pension Fund Investments in Real Estate. Journal of Financial Markets, 22, 73-103. https://doi.org/10.1016/j.finmar.2014.11.002

Andonov, A., Kok, N., \& Eichholtz, P. (2013). A Global Perspective on Pension Fund Investments in Real Estate. The Journal of Portfolio Management Special Real Estate Issue, 39, 32-42. https://doi.org/10.3905/jpm.2013.39.6.032

Andonov, A., Krauessl, R., \& Rauh, J. (2018). The Subsidy to Infrastructure as an Asset Class. Working Paper No. 25045, the National Bureau of Economic Research. https://doi.org/10.3386/w25045

Aubry, J., Chen, A., \& Munnell, A. H. (2017). A First Look at Alternative Investments and Public Pensions. State and Local Pension Plans, No. 55.

Craft, T. M. (2005). How Funding Ratios Affect Pension Plan Portfolio Allocations? Journal of Real Estate Portfolio Management, 11, 29-36. https://doi.org/10.1080/10835547.2005.12089710

Hoesli, M., \& Hamelink, F. (2004). Maximum Drawdown and Allocation to Real Estate. Journal of Property Research, 21, 161-206. https://doi.org/10.1080/0959991042000217903

Hoesli, M., MacGregor, B., Adair, A. S., \& McGreal, W. S. (2002). The Role of Real Estate in Mixed Asset Portfolios. In RICS (2002) Research Review Series. London: RICS Foundation.

Inderst, G. (2010). Pension Fund Investment in Infrastructure: What Have We Learnt? Pensions International Journal, 15, 89-99. https://doi.org/10.1057/pm.2010.4

IPF (1993). Report on Real Estate Investment for UK Pension Funds. London: The Investment Real Estate Forum \& the Working Group.

John, M. A., Larsson, T., Singull, M., \& Mushi, A. (2017). Projecting Tanzania Pension Fund System. African Journal of Applied Statistics, 4, 193-218. https://doi.org/10.16929/ajas/2017.193.210

Kironde, L. M. J., Mabere, R., \& Mutagwaba, H. (2003). Re-Establishing Effective Housing Finance Mechanisms in Tanzania: Potentials and Bottlenecks. Nairobi: UN-Habitat.

Kongela, S. M. (2005). The Dynamics in the Real Estate Sector in Tanzania for the Past 20 Years: The Case of NSSF and PPF. MBA Dissertation, Dar es Salaam: University of Dar es Salaam.

Kongela, S. M. (2013). Framework and Value Drivers for Real Estate Development in Sub-Saharan Africa: Assessment of the Tanzanian Real Estate Sector in the Context of the Competitiveness Model. Kologne: Immobilien Manager Verlag.

Kusiluka, M. M. (2012). Agency Conflicts in Real Estate Investment in Sub-Saharan Africa: Exploration of Selected Investors in Tanzania and the Effectiveness of Institutional Remedies. Kologne: Immobilien Manager Verlag.

Kusiluka, M. M., Kongela, S. M., \& Schulte, K. W. (2017). Land Use Policies and Markets in Some Selected African Countries. In G. Squires, E. Heuekens, \& R. Peiser (Eds.), Routledge Companion to Real Estate Development (pp. 70-79). Abingdon-on-Thames: Routledge.

Kwaku, K. (2007). The Investment Climate and Choices for Pension Funds in Africa. African Growth Agenda Newsletter, July-September.

Lim, L. C., McGreal, S., \& Webb, J. R. (2006). Perception of Real Estate Investment Opportunities in Central/South America and Africa. Journal of Real Estate Portfolio Management, 12, 261-276. https://doi.org/10.1080/10835547.2006.12089743 
Mensonides, J. (1998). Institutional Investors in the Netherlands: The Pension Plan for Dutch Civil Servant. In OECD (1998) Institutional Investors in the New Financial Landscape (pp. 277-295). Paris: OECD Publishing.

Meredith, M. (2006). The State of Africa: A History of Fifty Years of Independence. London: Free Press.

Newell, G. (2010). The Significance of Real Estate in Asian Pension Funds. Asia Pacific Real Estate Association, APREA Research Report.

Newell, G., Acheampong, P., \& Du Plessis, P. (2002). The Real Estate Markets in South Africa. Journal of Real Estate Literature, 20, 279-294.

OECD (2013). Asset Allocation of Pension Funds and Public Pension Reserve Funds. In Pensions at a Glance 2013: OECD and G20 Indicators (pp. 16-362). Paris: OECD Publishing.

OECD (2017). OECD Survey of Investment Regulation of Pension Funds. Paris: OECD Publishing.

OECD (2018). OECD Survey of Investment Regulation of Pension Funds. Paris: OECD Publishing.

PREA (2006). An International Comparative Study of the Pension Plan Community and Real Estate Investment. Pension Real Estate Association.

Rothenberger, S. (2010). Foreign Real Estate Investment in Sub-Saharan Africa: A Behavioural Approach in Countervailing the Investment Stigma by Image Analysis and EXploration of the Tanzanian Real Estate Market. Cologne: Immobilien Manager Verlag.

Ryck, K. D. (1998). Asset Allocation, Financial Market Behaviour and Impact on EU Pension Funds on European Capital Markets. In OECD (1998) Institutional Investors in the New Financial Landscape (pp. 267-333). Paris: OECD Publishing.

Shahab, S., \& Viallon, F. (2019). A Transaction-Cost Analysis of Swiss Land Improvement Syndicates. Town Planning Review, 90, 545-565. https://doi.org/10.3828/tpr.2019.34

Shahab, S., Clinch, J. P., \& O’Neill, E. (2018). Estimates of Transaction Costs in Transfer of Development Rights Programs. Journal of the American Planning Association, 84, 61-75. https://doi.org/10.1080/01944363.2017.1406816

Sharpe, W. F., Alexander, G. J., \& Bailey, J. V. (1999). Investments: International Edition (6th ed.). London: Prentice Hall International Inc.

Tamagno, E. (2000). Investing in Social Security Funds: Principles and Considerations. In ISSA Conference (pp. 1-15). Bangkok: Caledon Institute of Social Policy.

The Citizen Reporter (2018). NSSF Collects Shs. 20 Billion from Kigamboni Bridge. The Citizen. https://www.thecitizen.co.tz/news/1840340-4625356-5flrnfz/index.html

Van Nieuwerburgh, S., Stanton, R., \& de Bever, L. (2015). A Review of Real Estate and Infrastructure Investments by the Norwegian Government Pension Fund Global. Study, GPFG, Oslo.

Worzala, E. M., \& Bajtelsmit, V. L. (1993). Real Estate Allocation in Pension Fund Portfolios. Journal of Real Estate Portfolio Management, 1, 25-38. 